\title{
Prediction Of Water Quality Of Bicarbonate Mineral Water In WUDALIANCHI Based on BP Neural Network Model
}

\author{
ZENG Ying ${ }^{1,2}$, YANG Chen ${ }^{1,2}$, WANG Xiying ${ }^{1,2}$, FANG Zhenxing ${ }^{1,2}$, WU Jing J $^{1,2}$ \\ ${ }^{1}$ Institute of Volcano and Spring, Heilongjiang Academy of sciences, harbin Heilongjiang \\ ${ }^{2}$ Institute of Advanced Technology, Heilongjiang Academy of sciences, harbin Heilongjiang
}

\begin{abstract}
In order to grasp the water quality change trend and predict the future water quality characteristics of the bicarbonate mineral water in WUDALIANCHI, using the measured data from 2008 to 2016 of north drink spring in WUDALIANCHI as the predicted sample, carbon dioxide, total soluble solids, strontium and metasilicic acid which can divide mineral water type as analysis factor, the BP neural network combination forecast model was contructed. The results showed that the BP neural network combination forecast model was obviously more precise and better than grey system model, its average relative error was controlled within $5 \%$. The results indicated that the BP neural network combination forecast model can effectively predict the change trend of water quality of bicarbonate mineral water in WUDALIANCHI.
\end{abstract}

\section{Introduction}

As a world renowned spring, the mineral water spring in WUDALIANCHI enjoys the reputation of "sacred spring" and "holy water" and the same popularity with the Vichy in France and the north Caucasus mineral water in Russian. For thousands of years for medical, drinking and washing treatment history, it has a magical effect to the patients and the human health and longevity. The medicine spring mountain iron bicarbonate carbonate mineral water is developed the most comprehensively and has the most recognition of tourists and consumer, as a unique feature brand of WUDALIANCHI .

The current development of mineral water in WUDALIANCHI is in a state of relatively extensive, without the scientific planning and strict control, which leads to the negative market evaluation about the falling mouthfeel and the query on its quality and efficacy. This is a great test on the mineral water industry in WUDALIANCHI. Although the composition of natural mineral water is relatively stable within the natural cycle fluctuation range, it will also be affected by the surrounding environment and mining.

Based on the measured data from 2008 to 2016 of north drink spring in WUDALIANCHI as the predicted sample, using carbon dioxide, total soluble solids, strontium and metasilicic acid which can divide mineral water quality type as analysis factor, the BP neural network combination forecast model was contructed and its feasibility and applicability were discussed, in order to provide the reference basis for mining, pollution control and supervision for natural mineral water source in WUDALIANCHI, also to establish foundation for water quality forecast system engineering.

\section{Establishment and Application of the BP neural network combined prediction model}

Artificial Neural Network is a mathematical model abstracted by virtue of some features of the brain and nervous system to store and process information. It can simulate some intelligent behaviors of the human brain, such as perception, inspiration and image thinking, with the characteristics of self-learning, self-organization, selfadaptation and nonlinear dynamic processing. It has been widely used in water, atmosphere, soil and other environmental monitoring fields ${ }^{[1-5]}$. Affected by hydrogeological parameters, weather conditions, irrigation and drainage and other factors, groundwater quality dynamic has the characteristics of periodicity and randomicity and strong nonlinear, which can meet the characteristics of groundwater quality change, which provides a new way for the underground water quality prediction.

Based on gray system forecast result as input of forecasting model, neural network method to determine the weight of each model, this neural network combination forecast model operated. Using the measured data of the carbon dioxide, total dissolved solid, metasilicic acid and strontium from 2008 to 2016 of north drink spring in WUDALIANCHI as the predicted results to indicate the application effect of the model. To further narrow the model calculation error and improve the prediction accuracy, the second neural network prediction was operated, combining the predicted value of neural network prediction and gray prediction at the first time as the combination of forecast model input.

\footnotetext{
*Corresponding author: 76109538@qq.com
} 


\section{Data and Analysis}

In table 1, The measured results, predicted results and error percentage of the water quality index of the north drink spring in WUDALIANCHI in 2009 and 2016 on the grey system model and the combined model of BP neural network were listed. The results showed that the BP neural network combination forecast model was obviously more precise and better than grey forecasting model, its average relative error was controlled within 5\%. The results indicated that BP neural network combination forecast model can effectively predict the change trend of water quality of bicarbonate mineral water in WUDALIANCHI.

Table1 The measured results, predicted results and error percentage of the water quality index of the north drink spring in WUDALIANCHI in 2009 and 2016 on the grey system model and the combined model of BP neural network

\begin{tabular}{|c|c|c|c|c|c|}
\hline \multicolumn{2}{|c|}{ Year } & \multirow{2}{*}{$\begin{array}{r}\text { Carbon } \\
\text { dioxide } \\
1923.93\end{array}$} & \multirow{2}{*}{$\begin{array}{c}\begin{array}{c}\text { Total soluble } \\
\text { solids }\end{array} \\
2077.44 \\
\end{array}$} & \multirow{2}{*}{$\begin{array}{c}\begin{array}{c}\text { Metasilicic } \\
\text { acid }\end{array} \\
96.92\end{array}$} & \multirow[t]{2}{*}{ Strontium } \\
\hline \multirow{5}{*}{2009} & The measured results $(\mathrm{mg} / \mathrm{L})$ & & & & \\
\hline & $\begin{array}{l}\text { predicted results on the grey system } \\
\text { model }(\mathrm{mg} / \mathrm{L})\end{array}$ & 1860.84 & 2093.82 & 106.25 & \\
\hline & $\begin{array}{l}\text { predicted results on the BP neural } \\
\text { network combination forecast } \\
\text { model }(\mathrm{mg} / \mathrm{L})\end{array}$ & 1898.95 & 2077.25 & 96.94 & \\
\hline & $\begin{array}{l}\text { error percentage of the grey system } \\
\text { model }\end{array}$ & 3.82 & -0.79 & 0.08 & \\
\hline & $\begin{array}{l}\text { error percentage of the BP neural } \\
\text { network combination forecast mode }\end{array}$ & 1.298 & 0.0091 & -0.0275 & \\
\hline \multirow{5}{*}{2010} & The measured results $(\mathrm{mg} / \mathrm{L})$ & 1668.78 & 2091.64 & 111.96 & 0.76 \\
\hline & $\begin{array}{l}\text { predicted results on the grey system } \\
\text { model }(\mathrm{mg} / \mathrm{L})\end{array}$ & 1827.59 & 2124.33 & 101.68 & 0.76 \\
\hline & $\begin{array}{l}\text { predicted results on the BP neural } \\
\text { network combination forecast } \\
\text { model }(\mathrm{mg} / \mathrm{L})\end{array}$ & 1709.06 & 2116.32 & 111.96 & 0.7612 \\
\hline & $\begin{array}{l}\text { error percentage of the grey system } \\
\text { model }\end{array}$ & -3.64 & -1.56 & 0.12 & \\
\hline & $\begin{array}{l}\text { error percentage of the BP neural } \\
\text { network combination forecast mode }\end{array}$ & -2.413 & -1.18 & -0.0026 & \\
\hline \multirow{5}{*}{2011} & The measured results $(\mathrm{mg} / \mathrm{L})$ & 1828.17 & 2170.37 & 98.84 & 0.77 \\
\hline & $\begin{array}{l}\text { predicted results on the grey system } \\
\text { model }(\mathrm{mg} / \mathrm{L})\end{array}$ & 1794.94 & 2155.28 & 97.31 & 0.51 \\
\hline & $\begin{array}{l}\text { predicted results on the BP neural } \\
\text { network combination forecast } \\
\text { model }(\mathrm{mg} / \mathrm{L})\end{array}$ & 1828.35 & 2170.03 & 97.99 & 0.776 \\
\hline & $\begin{array}{l}\text { error percentage of the grey system } \\
\text { model }\end{array}$ & 5.39 & 0.7 & -4.1 & 0.81 \\
\hline & $\begin{array}{l}\text { error percentage of the BP neural } \\
\text { network combination forecast mode }\end{array}$ & -0.009 & 0.0158 & 0.8552 & -0.662 \\
\hline \multirow{5}{*}{2012} & The measured results $(\mathrm{mg} / \mathrm{L})$ & 1855.18 & 2208.49 & 101.37 & 0.81 \\
\hline & $\begin{array}{l}\text { predicted results on the grey system } \\
\text { model }(\mathrm{mg} / \mathrm{L})\end{array}$ & 1762.88 & 2186.69 & 93.13 & 0.88 \\
\hline & $\begin{array}{l}\text { predicted results on the BP neural } \\
\text { network combination forecast } \\
\text { model }(\mathrm{mg} / \mathrm{L})\end{array}$ & 1796.62 & 2206.67 & 97.39 & 0.798 \\
\hline & $\begin{array}{l}\text { error percentage of the grey system } \\
\text { model }\end{array}$ & 6.46 & 0.99 & 6.41 & -6.85 \\
\hline & $\begin{array}{l}\text { error percentage of the BP neural } \\
\text { network combination forecast mode }\end{array}$ & 3.156 & 0.0822 & 3.9253 & -1.126 \\
\hline \multirow{5}{*}{2013} & The measured results( $\mathrm{mg} / \mathrm{L})$ & 1592.97 & 2180.93 & 89.48 & 1.03 \\
\hline & $\begin{array}{l}\text { predicted results on the grey system } \\
\text { model }(\mathrm{mg} / \mathrm{L})\end{array}$ & 1731.38 & 2218.55 & 89.13 & 0.96 \\
\hline & $\begin{array}{l}\text { predicted results on the BP neural } \\
\text { network combination forecast } \\
\text { model }(\mathrm{mg} / \mathrm{L})\end{array}$ & 1660.26 & 2183.64 & 89.39 & 1.025 \\
\hline & $\begin{array}{l}\text { error percentage of the grey system } \\
\text { model }\end{array}$ & -9.69 & -1.73 & 2.05 & 5.89 \\
\hline & $\begin{array}{l}\text { error percentage of the BP neural } \\
\text { network combination forecast mode }\end{array}$ & -4.224 & -0.124 & 0.1039 & 1.597 \\
\hline \multirow[b]{2}{*}{2014} & The measured results $(\mathrm{mg} / \mathrm{L})$ & 1679.75 & 2282.15 & 75.99 & 1.1 \\
\hline & $\begin{array}{l}\text { predicted results on the grey system } \\
\text { model }(\mathrm{mg} / \mathrm{L})\end{array}$ & 1700.45 & 2250.88 & 85.3 & 1.05 \\
\hline
\end{tabular}




\begin{tabular}{|c|c|c|c|c|c|}
\hline & $\begin{array}{l}\text { predicted results on the BP neural } \\
\text { network combination forecast } \\
\text { model }(\mathrm{mg} / \mathrm{L})\end{array}$ & 1731.88 & 2281.29 & 75.69 & 1.106 \\
\hline & $\begin{array}{l}\text { error percentage of the grey system } \\
\text { model }\end{array}$ & -5.16 & 1.37 & -6.71 & 1.21 \\
\hline & $\begin{array}{l}\text { error percentage of the BP neural } \\
\text { network combination forecast mode }\end{array}$ & -3.103 & -0.006 & 0.3927 & 0.6543 \\
\hline \multirow{5}{*}{2015} & The measured results $(\mathrm{mg} / \mathrm{L})$ & 1888.37 & 2313.92 & 75.71 & 1.19 \\
\hline & $\begin{array}{l}\text { predicted results on the grey system } \\
\text { model }(\mathrm{mg} / \mathrm{L})\end{array}$ & 1670.08 & 2283.68 & 81.63 & 1.15 \\
\hline & $\begin{array}{l}\text { predicted results on the BP neural } \\
\text { network combination forecast } \\
\text { model }(\mathrm{mg} / \mathrm{L})\end{array}$ & 1821.44 & 2313.9 & 76.04 & 1.191 \\
\hline & $\begin{array}{l}\text { error percentage of the grey system } \\
\text { model }\end{array}$ & 5.03 & 1.31 & 0.76 & -1.89 \\
\hline & $\begin{array}{l}\text { error percentage of the BP neural } \\
\text { network combination forecast mode }\end{array}$ & 3.54 & 0.0008 & -0.4315 & -0.5924 \\
\hline \multirow{5}{*}{2016} & The measured results $(\mathrm{mg} / \mathrm{L})$ & 1506.43 & 2289.3 & 83.41 & 1.21 \\
\hline & $\begin{array}{l}\text { predicted results on the grey system } \\
\text { model }(\mathrm{mg} / \mathrm{L})\end{array}$ & 1640.24 & 2316.95 & 78.12 & 1.25 \\
\hline & $\begin{array}{l}\text { predicted results on the BP neural } \\
\text { network combination forecast } \\
\text { model }(\mathrm{mg} / \mathrm{L})\end{array}$ & 1494.84 & 2289.28 & 83.38 & 1.207 \\
\hline & $\begin{array}{l}\text { error percentage of the grey system } \\
\text { model }\end{array}$ & -8.88 & -1.21 & 6.34 & -3.79 \\
\hline & $\begin{array}{l}\text { error percentage of the BP neural } \\
\text { network combination forecast mode }\end{array}$ & 0.769 & 0.0008 & 0.0372 & 0.051 \\
\hline
\end{tabular}

\section{Results and Discussion}

This study established the BP neural network combination forecast model which had higher prediction accuracy than the grey system forecasting model on the water quality of bicarbonate mineral water of WUDALIANCHI, it can better capture the nonlinear change law of water quality indicators. However, the prediction factors selected in this study were relatively stable characteristic index of water quality of mineral water. The prediction accuracy of the pollution index with high volatility has not been verified, which needs further verification. In addition, it remains to be further studied whether the model can be applied to the prediction of surface water quality related to the water quality of underground mineral water.

\section{References}

1. Deswal S, Pal M. Int J Math, Phys Engin Sci, (4):177181, 22 (2008)

2. SHEN Haoyang, WEI Anlei,WANG Xiaowen et al. Envir Moni \& Asse, (6): 117-121, 3232( 2014)

3. ZHANG Qing, WANG Xuelei, ZHANG Ting et al. WET SCI, (2): 212-217, 14 (2016)

4. JU Zhenchuang, WANG Xiao, GONG Yanxia. J. Qinghai Uni, (3): 88-92, 35 (2017)

5. YANG W G, YE Z. IEEE Trans Infor Ther, (9) : 3275-3280, 53(2007) 